\title{
CZYTELNOŚĆ HISTORII KOMPLEKSU PRZEMYSKOWEGO PO JEGO ADAPTACJI DO NOWEJ FUNKCJI. OMÓWIENIE NA KILKU BYDGOSKICH PRZYKŁADACH
}

DOI: 10.37660/integr.2020.6.2.5

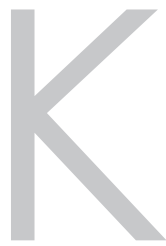

ompleksy poprzemysłowe stanowia coraz lepiej rozpoznawalny element dziedzictwa kulturowego. W Polsce, w której okres PRL „zakonserwował" wiele przedwojennych zakładów przemysłowych, zachowało się szczególnie dużo historycznych kompleksów produkcyjnych. Ich przetrwanie było możliwe dzięki specyficznym cechom gospodarki centralnie sterowanej.

Wiele przedsiębiorstw wkroczyło w okres przemian ustrojowych w latach 1989-1990 z ogromnym zasobem historycznych budynków przemysłowych, a także maszyn i linii produkcyjnych, kłóre w żadnym stopniu nie odpowiadały nowoczesnym metodom produkcji stosowanym w krajach zachodnich'. Aby sprostać konkurencji, zakłady przemysłowe musiały wprowadzić zdecydowane działania modernizujace i usprawniajace metody produkcji. Historyczne budynki nie odpowiadały potrzebom nowoczesnych linii produkcyjnych, co rodziło potrzebę rozbudowy zakładów przemysłowych. W wielu przypadkach brak rezerw terenu przy zakładach przemysłowych, a także wysoka uciążliwość produkcji dla mieszkańców wymuszały przeniesienie produkcji na mniej zurbanizowane tereny. Część zakładów przemysłowych nie przetrwała wolnorynkowej konkurencji i upadła ${ }^{2}$. W obu tych przypadkach zakłady pozostawiały po sobie opuszczone historyczne budynki przemysłowe, nierzadko zajmujace bardzo atrakcyjne działki w centrach miast. Problem ich ponownego wykorzystania stawał się coraz bardziej naglacy, w miare jak poczawszy od lat 90. XX wieku liczba opuszczonych fabryk stale rosła.

Oczywiście sam fakt przetrwania historycznego obiektu przemysłowego nie jest wystarczający dla uznania konieczności jego dalszego zachowania i konserwacji. Niemniej jednak wiele spośród nich w istocie jest nośnikiem ważnych wartości kulturowych. Szczególnie pełnienie roli dużego pracodawcy przez wiele dziesięcioleci, a także często występująca lokalna duma z produkowanego asortymentu sprawiaja, iż niejednokrotnie kompleksy przemysłowe stanowia istotny element budowania tożsamości miejsca dla mieszkańców, co z kolei przekłada się na bardzo wysokq wartość historyczno-emocjonalna ${ }^{3}$.

mgr inż. arch. Zuzanna Małkowska, https://orcid.org/0000-0001-6769-7218, Katedra ArchitekturyiUrbanistyki, Wydział Budownictwa, Architekturyi Inżynieriiśrodowiska, UniwersyłetTechnologiczno-Przyrodniczy im. Jana i Jędrzeja Śniadeckich w Bydgoszczy, doktorantka na Wydziale Budownictwa, Architektury i Inżynierii Środowiska Politechniki Łódzkiej

I S. Kamosiński, 2007. Mikroekonomiczny obraz przemysłu Polski Ludowej w latach 1950-1980 na przykładzie regionu kujawsko-pomorskiego. Poznań, s. 316-334.

2 S. Kamosiński, 2015. Przedsiębiorstwa w przebudowie. Prywatyzacja i restrukturyzacja przedsiębiorstw kujawsko-pomorskich w latach 1990-2004. Bydgoszcz, s. 166-272.

3 Nazwy wartości kulturowych przyjęto za: J.J. Tajchman, 2014. Standardy w zakresie projektowania, realizacji i nadzorów prac konserwatorskich dotyczących zabytków architektury 
Warto także wspomnieć, iż w XXI wieku pojawiła się bardzo wyraźna moda na industrialna stylistykę, szczególnie widoczna w obiekłach usługowych, biurowych i mieszkalnych. Spowodowała ona wzmożone zainteresowanie inwestorów budynkami o przemysłowej przeszłości. Niesteły nie zawsze pomagała zachować rzeczywistą formę budynków czy realne technofakty ${ }^{4}$.

W ramach prowadzonych badań postawiono za cel weryfikację, czy adapłacje historycznych kompleksów przemysłowych do nowych funkcji użytkowych przebiegaja z poszanowaniem dla historii miejsca. Szczególny nacisk położono na aspekt zachowania zbiorowej pamięci o pierwołnej, przemysłowej funkcji terenu, to jest zachowania wartości historyczno-emocjonalnej kompleksu.

Wielu autorów, opisujących studia przypadków pojedynczych adaptacji lub miast postindustrialnych, porusza temat wagi wartości historyczno-emocjonalnej dla przetrwania dziedzictwa przemysłowego. Autorem, który bezpośrednio rozważa kwestie zbiorowej pamięci oraz zbiorowego zapominania w odniesieniu do dziedzictwa techniki, jest Waldemar Affelt, który szczególnie szeroko omówił temał w jednym ze swoich artykułów ${ }^{5}$, ale porusza go również w publikacji przedstawiającej autorską metodę wartościowania zabytków techniki „Technitas"6.

Aby poszerzyć wiedzę z tego zakresu, zdecydowano się na przeprowadzenie badań metoda wielokrotnego studium przypadku, przyjmując do badań kilka historycznych kompleksów poprzemysłowych z obszaru Bydgoszczy?. Dla każdego z kompleksów przeprowadzono analizę doniesień prasowych pod kątem występowania odniesień do przemysłowej historii miejsca i zachowania dziedzictwa niematerialnego zakładu, a także występowania kompleksu w przewodnikach turystycznych i na proponowanych przez miasto trasach wycieczek. Ponadto autorka, bazujac na kwerendzie archiwalnej i wizji lokalnej, przeprowadziła analizę przekształceń przestrzennych kompleksów po roku 1990, oceniajac ich wpływ na zmianę percepcji przestrzennej założenia. Kompleksy miały być wyraźnie zróżnicowane pomiędzy soba, np. zajmowana powierzchnia, lokalizacja w mieście, sposób wprowadzania nowej funkcji. Część z nich była już wspominana w publikacjach (w tym publikacjach autorki). Inne jednak sa bardzo mało znane, a ich uwzględnienie w dyskusji daje pełniejszy obraz skomplikowanego procesu adaptacji kompleksów poprzemysłowych do współczesnych funkcji użyłkowych oraz możliwości zachowania czytelności historii miejsca. Dzięki temu końcowe wnioski wyciagnięte z porównania poszczególnych przypadków metodą indukcji maja szansę mieć charakter bardziej uniwersalny.

i budownictwa. Toruń - Warszawa, s. 9-10.

4 Termin „technofakt” został wprowadzony przez Waldemara Affelta przez analogię do słowa "artefakt” i definiowany jest jako „wszystkie składniki dziedzictwa kulturowego techniki”, w niniejszym opracowaniu określenia „„echnofakt” używa się szczególnie dla określenia maszyn, technicznego wyposażenia, pozostałości po instalacjach, które zachowały się po działalności przemysłowej, patrz: W.J. Affelt, 2015. Technitas: konteksty dziedzictwa kulturowego techniki. Zabrze, s. 17.

5 W.J. Affelt, 2014. Program funkcjonalno-użyłkowy rewitalizacji zasobu dziedzictwa techniki wobec jego wartościowości i pamięci kulturowej. [W:] Wartość funkcji w obiektach zabytkowych, red. B. Szmygin, Warszawa.

6 W.J. Affelt, Technitas..., op. cit.

7 Wszystkie prezentowane przykłady analizowane sa w innym kontekście w ramach opracowywanej na Wydziale Architektury i Inżynierii Środowiska Politechniki Łódzkiej pracy dokłorskiej autorki pod kierunkiem dr. hab. inż. arch. Jana Salma oraz dr. inż. arch. Włodzimierza Witkowskiego. 
Drukarnia Gruenauera była pierwsza drukarnia w Bydgoszczy. W 1815 roku rozpoczęła działalność na terenie nieruchomości kupionej od klasztoru sióstr klarysek, zlokalizowanej przy obecnej ulicy Jagiellońskiej 1. W tymże roku powstał frontowy budynek mieszkalno-administracyjny o charakterystycznym naczółkowym dachu oraz zabudowania produkcyjne w głębi działki. Kolejne znaczące rozbudowy drukarni nastapiły w latach 1899-1909 oraz 1949-57, powodując stopniowe powiększanie się zakładu w kierunku północnym ${ }^{8}$

Drukarnia, zmieniając nazwy i właścicieli, pełniła swoja funkcję do roku 2005. W ostatnich latach produkcji (od roku 1985) znana była jako Zakłady Graficzne im. Komisji Edukacji Narodowej. Zakłady w roku 2005 przeniosły się do podbydgoskiej miejscowości Brzoza, by po dwóch latach ogłosić postępowanie upadłościowe? Teren po Drukarni Gruenauera został sprzedany inwestorowi pod budowę centrum handlowego. Wszystkie zabudowania zostały wyburzone, a na ich miejscu w 2007 roku powstał budynek centrum handlowego zajmujący cała powierzchnię pierwotnego kompleksu drukarni. Po pierwotnej funkcji terenu pozostały dwa ślady.

Pierwszym sa odtworzone elewacje frontowa i boczne frontowego budynku administracyjno-mieszkalnego z 1815 roku. Ściany nie sa oryginalnymi reliktami, zostały zbudowane na nowo podczas realizacji inwestycji. Ponadto zostały przesłonięte nowa szklana elewacja, która została umieszczona na samonośnej konstrukcji przed odtworzona fasada (rys. 1). Niestety zdecydowano się na odtworzenie wyłącznie dwóch kondygnacji ścian zewnętrznych, całkowicie pominięto charakterystyczny dach naczółkowy oraz ściany szczytowe poddasza. Całość sprawia wrażenie inscenizacji, niewiele mającej wspólnego z pierwotnym zagospodarowaniem kompleksu. Ukłonem w kierunku uszanowania pierwotnej organizacji przestrzeni miało być zapewne zlokalizowanie głównego wejścia do budynku w miejscu pierwotnego wejścia na teren kompleksu - z narożnika ulicy Jagiellońskiej i 19 Marca 1981 roku (dawniej Parkowa). Na tym jednak kończa się fizyczne powiązania

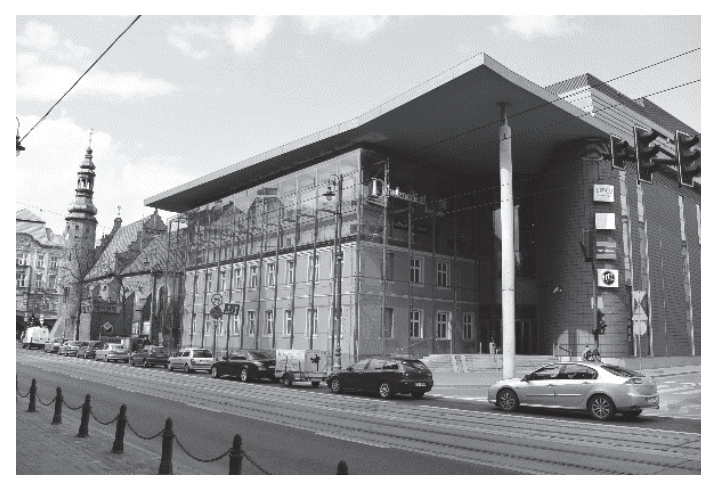

Rys. 1. Budynek Domu Mody Drukarnia (późniejsze Bydgoskie Centrum Finansowe) od strony południowo-wschodniej; za szklana elewacja widoczne zrekonstruowane ściany zewnętrzne pierwotnego budynku frontowego Drukarni Gruenauera; rezygnacja z pokazania pierwotnego dachu naczółkowego powoduje drastyczna zmianę w odbiorze bryły budynku (fot. autorka, 2014)

Fig. 1. Fashion House Printinghouse building (later Bydgoszcz Financial Center), the view from south-east; behind the glass facade the front walls of original Gruenaver Printhouse building were reconstructed; the lack of original pediment roof causes dramatic change of perception of the building (photo by author, 2014)

8 M. Grzybowska, Karta Ewidencyjna Zabytków Architektury i Budownictwa z roku 1995: Dom mieszkalny Gruenavera, ob. budynek główny administracji w zespole Drukarni Gruenavera, ob. Zakłady Graficzne im. KEN S. A., przechowywana w zbiorach Wojewódzkiego Urzędu Ochrony Zabytków w Toruniu, Delegatura w Bydgoszczy.

9 J. Umiński, 2009. Zakłady Graficzne. [W:] Kalendarz Bydgoski na rok 2010, Bydgoszcz, s. $307-311$. 
nowego centrum handlowego z pierwotnym kompleksem drukarni. Architektura nowego obiektu w żaden sposób nie nawiqzuje do pierwotnych form, a we wnętrzach próżno szukać odniesień do bogatej historii drukarskiej miejsca.

Drugim śladem po pierwotnej funkcji terenu stała się nazwa nowo wybudowanego centrum handlowego: Dom Mody Drukarnia. Z punktu widzenia klasycznie rozumianej konserwacji zabyłków wydawać by się mogło, że jest to pusty gest, który w żadnym stopniu nie wpływa na zachowanie wartości kulturowych kompleksu (szczególnie w kontekście całkowitego wyburzenia wszystkich budynków wchodzących w jego skład). Jednak biorac pod uwagę koncepcję dziedzictwa niematerialnego, należy z całą stanowczościa stwierdzić, iż sama nazwa pierwotnej funkcji może zostać uznana za dziedzictwo kulturowe miejsca. Ponadto należy podkreślić, iż zachowanie pamięci o pierwotnej funkcji miejsca utrwala wartość historyczno-emocjonalna kompleksu, a w konsekwencji przedłuża pamięć o pierwotnej przemysłowej funkcji terenu. W tym kontekście należy ocenić, iż decyzja o przyjęciu nazwy Drukarnia dla nowo powstałego centrum handlowego przyczyniła się w znacznie większym stopniu do zachowania czytelności historii miejsca niż scenograficzne odtworzenie fasad jednego z budynków kompleksu.

Niestety w roku 2016, po zmianie właściciela, obiekł zmienił nieznacznie profil działalności, a wraz z nim nazwę na „Bydgoskie Centrum Finansowe”. Obecny właściciel deklaruje chęć kolejnej zmiany nazwy obiektu na „Nowa Drukarnia”10.

Kolejnym przykładem adaptacji kompleksu poprzemysłowego na centrum handlowe jest rzeźnia miejska. Powstała ona w roku 1890 na ówczesnych obrzeżach Bydgoszczy. Została założona jako zakład komunalny w związu z zaostrzeniem przepisów sanitarnych w państwie pruskim. W roku 1894 na terenie przylegajacym do rzeźni od zachodu założono targowicę miejska, czyli miejsce handlu zwierzętami rzeźnymi. W latach 1893-1910 wybudowano budynki administracyjne i socjalne rzeźni oraz łargowicy, zlokalizowane wzdłuż ulicy Jagiellońskiej, które otrzymały reprezentacyjna formę architektoniczna odpowiednia dla jednej z głównych ulic wjazdowych do miasta ${ }^{11}$. Przedsiębiorstwo funkcjonowało przez cały wiek XX, przejmujac także teren targowicy miejskiej. W 1995 roku rozpoczęto proces prywatyzacji firmy, który zaowocował planami przeniesienia produkcji na przemysłowe tereny miasta. W 2006 roku zakład przeniósł się do dzielnicy Brdyujście ${ }^{12}$, a teren przy ul. Jagiellońskiej został sprzedany pod budowę centrum handlowego. Jeszcze w tym samym roku wyburzono wszystkie budynki produkcyjne, zachowano natomiast i starannie odrestaurowano budynki administracyjno-socjalne zlokalizowane wzdłuż ulicy Jagiellońskiej. Na rozległym terenie ok. 5 ha powstał budynek centrum handlowego Focus Park, który przez kilka lat szczycił się tyłułem największego centrum handlowego w Bydgoszczy (rys. 2).

10 Wracaja sklepy do Drukarni w Bydgoszczy! Będzie Nowa Drukarnia, Gazeta Pomorska, https://pomorska.pl/wracaja-sklepy-do-drukarni-w-bydgoszczy-bedzie-nowa-drukarnia/ar/ c3-14415681 (dostęp: 19.05.2020).

11 J. Esman, 2013. Rzeźnia Miejska w Bydgoszczy 1939-1945. [w:] Kronika Bydgoska, T. 34, Bydgoszcz, s. 163-185.

12 W zwiazku ze złym zbilansowaniem ekonomicznym inwestycji w roku 2008 zakład ogłosił upadłość, patrz: https://pomorska.pl/bydmeat-i-kujawy-uda-sie-uratowac/ar/c3-6978403 (dostęp: 30.05.2020). 
Co ciekawe, starannie odrestaurowane zabytkowe budynki zlokalizowane wzdłuż ulicy Jagiellońskiej ${ }^{13}$ przez wiele lat nie mogły znaleźć najemców, bowiem nie zostały włączone w ciągi komunikacyjne samego centrum handlowego. Niemniej jednak ich obecność stanowi bardzo ważne świadectwo świadczace o tym, że jest to teren z bogata historia. Czy jednak da się odczytać, iż jest to historia przemysłowa? Same budynki zabytkowe nie maja cech charakterystycznych dla obiektów przemysłowych, bowiem nigdy nie pełniły funkcji produkcyjnej. Były to obiekty administracyjne i socjalne. Ponadto powstawały z myśla o stworzeniu godnej oprawy dla ważnej ulicy wlotowej do miasta, zatem ich architektura jest reprezentacyjna, dekoracyjna i urozmaicona, nie zdradzajaca przemy-

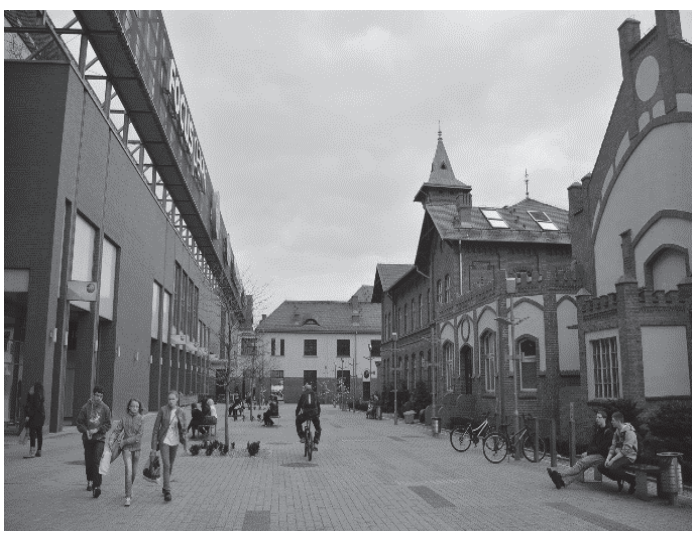

Rys. 2. Centrum handlowe Focus Park przy ul. Jagiellońskiej 41-47; po prawej stronie widoczne odrestaurowane budynki administracyjne dawnej rzeźni miejskiej, po lewej stronie nowy budynek centrum handlowego, zajmujacy niemal cała powierzchnię pierwotnego kompleksu przemysłowego (fot. autorka, 2015)

Fig. 2. Focus Park shopping mall, located by Jagiellońska street No 41-47; on the right restored buildings of old slaughterhouse, on the left new building of the shopping mall, that occupies almost whole area of the old industrial complex (photo by author, 2015) słowego powinowactwa. Z kolei analiza doniesień prasowych jasno pokazuje, że po otwarciu centrum handlowego odniesienia do pierwotnej funkcji miejsca zniknęły niemal całkowicie.

W inwestycji nie przewidziano także odwołań w nazewnicłwie, czemu trudno się dziwić wobec negatywnych konotacji słowa „rzeźnia". Nie zastosowano stylistyki odwołującej się do przemysłu ani nie wyeksponowano technofaktów. Wszystko to składa się na fakt, iż pomimo zachowania i odrestaurowania najcenniejszych budynków kompleksu jego przemysłowa historia pozostaje bardzo mało czytelna dla odbiorcy.

Jedna z najbardziej niezwykłych fabryk znajdujacych się w granicach administracyjnych miasta Bydgoszczy jest fabryka materiałów wybuchowych DAG Fabrik ${ }^{14}$. Zbudowana przez III Rzeszę w Puszczy Bydgoskiej podczas II wojny światowej, zajmuje obszar ok. $23 \mathrm{~km}^{2}$. W latach powojennych większość jej obszaru została przekształcona w ZACHEM, ale część stref produkcyjnych pozostała nieużytkowana, między innymi obiekty dwóch bliźniaczych linii produkcyjnych nitrogliceryny (łzw. strefa NGL). W roku 2007 cała strefa została przekazana Muzeum Okręgowemu im. Leona Wyczółkowskiego w Bydgoszczy. Muzeum wytypowało jedna z linii produkcyjnych, której budynki znajdowały

13 Odrestaurowanie zabytkowych budynków frontowych (wpisanych do Rejestru Zabyłków) było warunkiem Miejskiego Konserwatora Zabyłków dla realizacji inwestycji, kłóry został uwzględniony w miejscowym planie zagospodarowania przestrzennego.

${ }^{14}$ M. Pszczółkowski, 2010. Betonowa tajemnica. Fabryki materiałów wybuchowych DAG. Bydgoszcz, s. 90-92. 


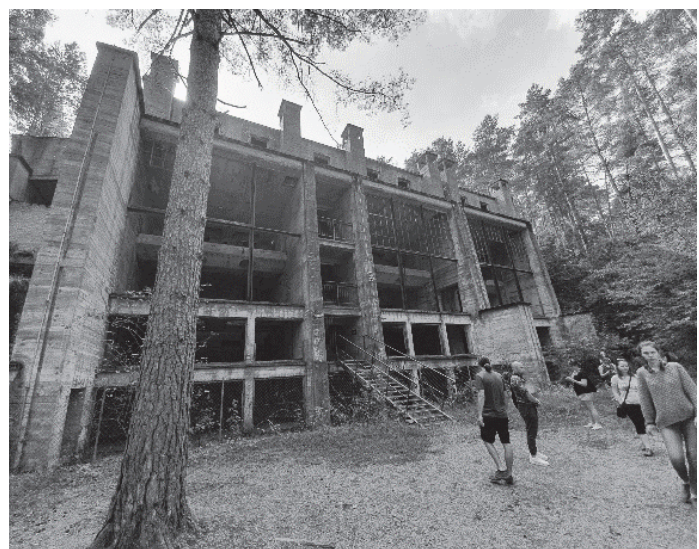

Rys. 3. Jeden z budynków dawnej fabryki materiałów wybuchowych DAG włączony do trasy zwiedzania Exploseum (fot. autorka, 2019)

Fig. 3. One of the buildings of the old DAG explosives factory, that was included in sightseing route of the Exploseum museum (photo by author, 2019)

się w lepszym stanie technicznym (prawdopodobnie nigdy nie były użytkowane), aby w 2011 roku otworzyć ja do zwiedzania jako Exploseum - centrum techniki wojennej DAG Fabrik Bromberg (filia Muzeum Okręgowego). Przygotowana ekspozycja pozwala zapoznać się z historia produkcji broni, materiałów wybuchowych, konfliktów zbrojnych, a także ze szczegółami procesu produkcyjnego w strefie NGL, pomimo całkowitego braku maszyn i wyposażenia, które zostało w całości wywiezione po II wojnie światowej do ZSRR ${ }^{15}$.

Większość budynków włączonych do trasy zwiedzania zostało odrestaurowanych, zabezpieczonych współczesnymi drzwiami i oknami (ponieważ oryginalne nie zachowały się przez długi czas nieużyłkowania). Część budynków jednak została tylko zabezpieczona $w$ formie trwałej ruiny, na przykład budynek mieszania nitrogliceryny z nitroceluloza (rys. 3), w którego wnętrzu umieszczono ekspozycję pomimo braku zamknięcia otworów okiennych.

Całość opowiada w barwny sposób historię miejsca, będąc czytelnym świadectwem działalności przemysłowej. Dodatkowym atutem jest pozostawienie wielu obiektów w formie ruiny w gęstej Puszczy Bydgoskiej, co dodatkowo pobudza wyobraźnię odwiedzajacych oraz pozwala na wykorzystanie miejsca na cele rekreacyjne, np. animacje i gry terenowe.

Muzeum było wielokrotnie nagradzane, zostało włączone do Europejskiego Szlaku Dziedzictwa Przemysłowego jako łzw. „punkt kotwiczny”, a przewodniki miejskie opisuja muzeum jako niezbędny punkt zwiedzania miasta.

Przykładem mało znanego kompleksu poprzemysłowego, zachowanego w bardzo dobrym stanie jest dawna Rafineria Spirytusu C.A. Frankego, zlokalizowana przy ul. Czartoryskiego 4-6. Niewielki zespół budynków został wybudowany w latach 1887-1902 na parceli o powierzchni zaledwie ok. 0,5 ha. Niektóre budynki w okresie II wojny światowej zostały nieznacznie przebudowane oraz zmieniły funkcję. Jeden z budynków mieszczacych zbiornik na spirytus został przekształcony na cele biurowe (rys. 4). Drugi budynek ze zbiornikiem na spirytus przekształcono w śrutownię. Czterokondygnacyjny budynek destylarni został rozebrany do poziomu parteru. W okresie powojennym budynki były adaptowane do zmieniajacych się funkcji (biurowej, usługowej, magazynowej), jednak nie były poddawane gruntownym przebudowom. Obecnie budynki wynajmowane

${ }^{15}$ M. Pszczółkowski, 2016. DAG Fabrik Bromberg. Z dziejów bydgoskiej fabryki materiałów wybuchowych 1939-1945. Bydgoszcz, s. 114-118. 
są różnym najemcom, znajdują się tam np. niewielka stolarnia, drukarnia, hurtownia, biura.

Kompleks sqisiaduje z Brdq-Młynówka, wchodzac W skład tzw. Wenecji Bydgoskiej. Pomimo tak atrakcyjnej lokalizacji, tuż obok Kładki Klenczona, prowadzacej bezpośrednio na Wyspę Młyńska, oraz charakterystycznej ceglanej architektury przemysłowej kompleks jest słabo rozpoznawalny przez mieszkańców miasta oraz nie występuje $w$ doniesieniach medialnych. Wydaje się, że wpływ na to ma kilka czynników. Po pierwsze brak tutaj dużego, monumentalnego budynku przemysłowego, który stanowiłby wyraźna dominantę (jak to ma miejsce np. w przypadku sasiadujacej Farbiarni Koppa, od wielu lat nieużytko-

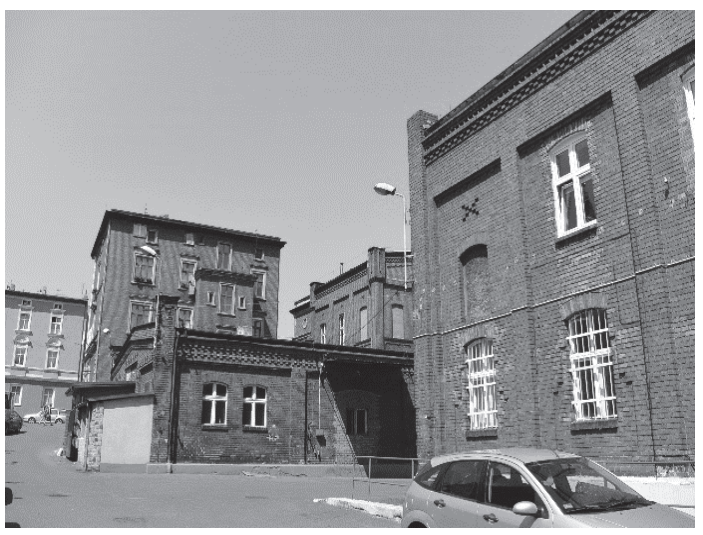

Rys. 4. Kompleks dawnej rafinerii spirytusu C.A. Frankego przy ul. Czartoryskiego 4-6; całkowicie spójny wygląd kompleksu, niepoddawanego większym przebudowom od czasów II wojny światowej (fot. autorka, 2014)

Fig. 4. Complex of the old C.A. Franke spirit refinery, located by Czartoryskiego street No 4-6; consistent appearance of the complex which practically wasn't changed since II World War (photo by author, 2014) wanej). W powszechnym mniemaniu fabryka powinna być dużym budynkiem, a nie zespołem mniejszych obiektów. Po wtóre, kompleks nadal jest ogrodzony przedwojennym parkanem i posiada tylko jedna bramę wjazdowa. Z jednej strony zapewnia to pełna czytelność zasięgu pierwotnego kompleksu. Jednak brak możliwości wejścia od strony Wyspy Młyńskiej i Młynówki znacząco utrudnia możliwość jego penetracji przez turystów czy przypadkowych przechodniów. I w końcu kompleks nie przenosi żadnych funkcji, które ściagną́ mogłyby większa liczbę użytkowników. Stolarnia wykonuje meble na wymiar i nie zaprasza klientów do swojej siedziby, a biura i drukarnia funkcjonuja głównie w formie zleceń. Brak funkcji generującej zwiększony ruch w połączeniu z zamkniętym charakterem kompleksu powoduje, że przechodnie po prostu nie maja okazji, żeby wejść na teren kompleksu i zapoznać się z jego zabudowa oraz historią.

Rafineria Spirytusu C.A. Frankego, zanim został wybudowany kompleks przy Czartoryskiego 4-6, opisywany powyżej, posiadała siedzibę przy ul. Podwale 2. Kompleks założony w roku 1872 znajdował się na Starym Mieście i miał powierzchnię zaledwie 0,16 ha. Obejmował swoim zasięgiem całość kwartału ograniczonego ulicami: Podwale, Kręta, Jatki oraz Grodzka. Destylarnia funkcjonowała równolegle z druga lokalizacja, przy Czartoryskiego, aż do wybuchu II wojny światowej. W czasie wojny część budynków wyburzono podczas likwidacji sqsiadującego od zachodu kwartału zabudowy, ograniczonego ulicami Grodzka, Jatki, Mostowa i Starym Rynkiem. Po wojnie zachowane budynki kompleksu były stopniowo adaptowane na funkcje mieszkaniowe, biurowe i rozrywkowe. Z kolei na miejscu po wyburzonym kwartale przy ul. Mostowej w latach 1967-1968 powstał bar szybkiej obsługi „Kaskada”, który zaburzył pierwołny układ przestrzenny 
i na kilkadziesią lat wymazał ulicę Jatki z mapy Bydgoszczy. Dopiero w roku 2008 bar „Kaskada” został wyburzony, a w jego miejsce w kolejnych latach wprowadzono kwartał nowej zabudowy, nawiązujacy do układu pierwotnego kwartału. Dzięki temu odtworzona została ulica Jatki, a obszar dawnej destylarni stał się jednym z najbardziej atrakcyjnych terenów inwestycyjnych w mieście.

W roku 2015 wybudowano budynek restauracyjno-biurowy u zbiegu ulicy Krętej i Jatki, kłóry wykończył pierzeje odtwarzanej ulicy Jatki. Jego ceglane elewacje z antracytowym detalem maja nieco industrialny charakter i zapewne miały nawiązywać do sasiedniego ceglanego budynku dawnej remizy lod roku 1991 siedziba klubu muzycznego ElJazz).

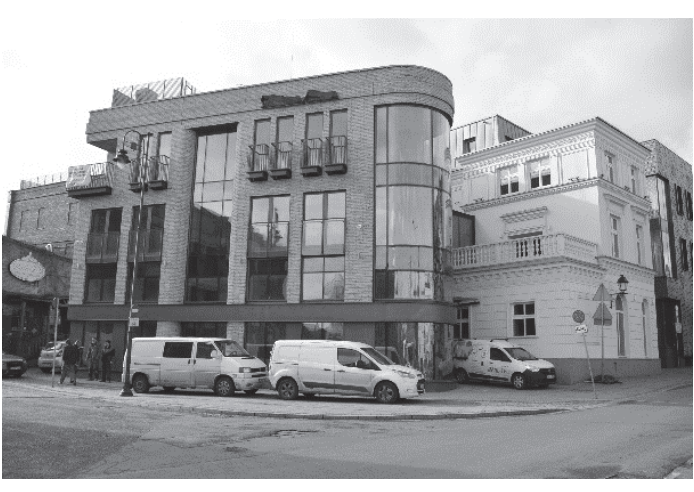

Rys. 5. Kompleks dawnej rafinerii spirytusu C.A. Frankego zlokalizowany przy ul. Podwale 2; w głębi widoczny biały budynek dawnej rafinerii spirytusu, rozbudowany o ceglana część widoczna na pierwszym planie i adaptowany na cele hotelowe (fot. autor$\mathrm{ka}, 2020$ )

Fig. 5. Complex of the old C.A. Franke spirit rafinery, located by Podwale street No 2; in the back white building of the old spirit refinery, that was expanded with a brick part in the front and adapted for a hotel function (photo by author, 2020)

Z kolei budynek dawnej rafinerii spirytusu, zlokalizowany wzdłuż ulicy Jałki aż do jej skrzyżowania z ulica Grodzka, został rozbudowany, nadbudowany i adaptowany na cele hotelowe w latach 2016-2019. Eklektyczna architektura obiektu destylarni, wybudowanego w 1872 roku, ma cechy wielkomiejskiej architektury, w niczym nie zdradzające produkcyjnej funkcji, jaka przenosił. Z kolei jego rozbudowa otrzymała ceglane elewacje w kolorze piaskowym z antracytowa stolarka i detalem. Dobór materiałowy daje nieco industrialny efekt, który jednak nie został podkreślony przez rozwiązania architektoniczne (rys. 5).

Teren po dawnej rafinerii spirytusu jest bardzo dobrze znany wszystkim mieszkańcom miasta, a od czasu odtworzenia ulicy Jatki także chętnie odwiedzany przez turystów. Jednak przez różnorodność architektury poszczególnych budynków, wprowadzenie całkowicie niezależnych funkcji do każdego z obiektów, a łakże brak wewnętrznej przestrzeni kompleksu (wszystkie budynki dostępne sa z ulic otaczających kompleks) istnienie w przeszłości kompleksu przemysłowego obejmujacego cały kwartał jest zupełnie nieczytelne. Nawet nowe budynki, które wystrojem elewacji wprowadzaja industrialna stylistykę, nie wpłynęły znaczaco na poprawę czytelności historii miejsca. Choć należy przyznać, że z dużym smakiem wpisały się współczesna architektura pomiędzy obiekty o cechach przemysłowych i wielkomiejskich, budujac nowa wartość w strukturze Starego Miasta. Co ciekawe, obiektem, który w żaden sposób nie zdradza cech przemysłowych, jest jedyny zachowany budynek produkcyjny zakładu, w którym naprawdę destylowane były wyroby spirytusowe (rys. 5). 
Wzdłuż ulicy Chocimskiej, przy zbiegu z ulica Kościuszki na początku XX wieku powstał duży nowoczesny budynek przemysłowy, do którego w roku 1912 przeniosła swoją działalność Fabryka Obuwia Weynerowskiego. Po wojnie kompleks, funkcjonujący pod nazwa „Kobra”, został znacząco rozbudowany na zachód i południe o nowe budynki przemysłowe i biurowe. Zakład produkował obuwie do roku 1992, kiedy ogłoszono upadłość przedsiębiorstwa. Budynki kompleksu były niezależnie adaptowane do nowych funkcji. W najstarszym budynku fabrycznym, o ciekawej artykulacji fasad łączącej elementy ceglane z tynkowanymi wnękami i neorenesansowymi szczyłami (rys. 6), swoja siedzibę znalazł cały szereg drobnych usług i biur. W parterze gładko wpisała się między innymi funkcja dyskontu spożywczego. W roku 2015 dokonano restauracji fasad budynku, w ramach której odrestaurowano i wyeksponowano także oryginalna kuta furtę prowadzaca na teren zakładu. Nad furta powieszono tablicę informująca o historii budynku. Niestety w roku 2018 furta została zasłonięta przez paczkomat, a pamiątkowa tablica przeniesiona $w$ inne, mniej eksponowane miejsce. Warto podkreślić, że liczne doniesienia prasowe na temat kompleksu niemal zawsze powołuja się na jego przemysłowa historię.

Część budynków powojennych zakładu podczas remontów otrzymała nowy wystrój fasad, utrzymany $w$ duchu industrialnej stylistyki. Choć maja one zupełnie współczesny charakter, to sygnalizuja, iż zakład przemysłowy nie ograniczał się do jednego budynku ciagnącego się wzdłuż ulicy

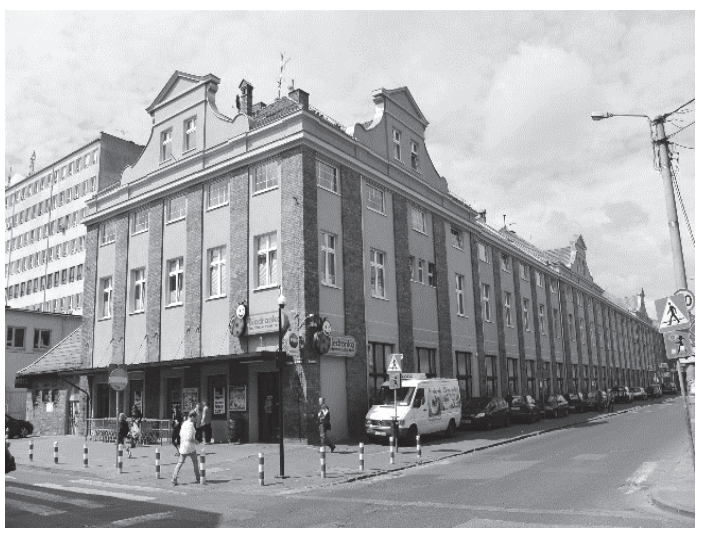

Rys. 6. Fabryka obuwia Weynerowskiego, po wojnie znana jako Kobra, zlokalizowana $\cup$ zbiegu ulic Chocimskiej i Kościuszki; po zaprzestaniu produkcji w roku 1992 była stopniowo adaptowana na cele handlowe i biurowe, w 2015 roku dokonano restauracji elewacji (fot. autorka, 2015)

Fig. 6. Weynerowski shoe fabric, after war known as Kobra, located on the corner of Chocimska and Kościuszki street; afer cessation of production in 1992 the factory was gradually adapted to commerce and office functions, in 2015 the facade of historic building was restored (photo by author, 2015)

Chocimskiej. Niestety największy powojenny budynek produkcyjny, zlokalizowany od strony ulicy Pomorskiej, o charakterystycznych cechach modernistycznych zabudowań przemysłowych, podczas adaptacji na cele biurowe zyskał także całkowicie nowa fasadę, która jest dobrze zaprojektowana elewacja współczesnego biurowca, jednak w żadnym stopniu nie sygnalizuje pierwotnej funkcji budynku.

Przy ulicy Unii Lubelskiej 4D, niespełna 200 metrów od dworca Bydgoszcz Główna, mieści się zespół budynków dawnego Browaru Wielkopolskiego. Pierwsze budynki kompleksu powstały prawdopodobnie już w latach 1872-187316. Pod koniec XIX wieku browar został poddany generalnej przebudowie. Do wybu-

${ }_{16}$ Program opieki nad zabytkami Miasta Bydgoszczy na lata 2013-2016. [W:] Uchwała nr XLI/875/13 Rady Miasta Bydgoszczy z dnia 24 kwietnia 2013 r., 2013. 
chu II wojny światowej produkowano w nim piwo, choć prawdopodobnie okresowo pełnił jedynie rolę rozlewni. Podczas wojny zabudowania zaadaptowano na pralnię, a po wojnie pełniły różne funkcje, głównie magazynów i hurtowni.

W roku 2013 jeden z obiektów dawnego browaru został zaadaptowany na centrum fitness (rys. 7). Wykorzystano ceglana architekturę do zbudowania identyfikacji wizualnej obiektu oraz aranżacji wnętrza. Wyeksponowano oryginalne stropy i sklepienia, podkreślono pierwotna konstrukcję, w tym stalowe podciagi i filary. Zachowano oryginalne podziały elewacji, w której jedyna trwała ingerencja jest wybicie szerokiego otworu wejściowego. Zdecydowano się również na nazwę, która odnosi się do przemysłu: "Cegielnia fit \& gym”. Jednak ani adaptowany budynek, ani teren, na kłórym się znajduje, nigdy nie pełnił roli cegielni. Zapew-

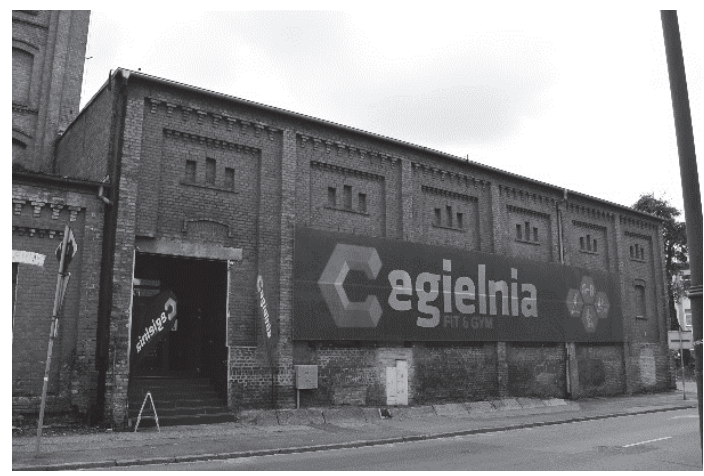

Rys. 7. Jeden z budynków dawnego Browaru Wielkopolskiego przy ul. Unii Lubelskiej 4D, adaptowany $w$ roku 2013 na cele centrum fitness o nazwie "Cegielnia", mimo iż w tym miejscu nigdy prawdziwa cegielnia nie istniała (fot. autorka, 2017)

Fig. 7. One of the buildings of Wielkopolski Brewery by Unii Lubelskiej street No 4D, that was adapted in 2013 to a fitness club named "Brickyard", though there never was a real brickyard in this location (photo by author, 2017)

\section{PODSUMOWANIE}

Adaptacja kompleksu poprzemysłowego do nowej funkcji to proces niezwykle złożony. Zrealizowanie go bez stracenia choćby niewielkiej części wartości kulturowych wydaje się niemożliwe. Warto jednak zawsze zadać pytanie, kłóre postawił Waldemar Affelt $w$ artykule podejmującym temat pamięci kulturowej: "Czy zmiana funkcji zabyłku i jego wartościowości upamiętnia przeszłość, czy służy jego zapomnieniu?"17. Przyłoczone przykłady z terenu Bydgoszczy pokazuja, że czytelność historii miejsca z jednej strony może być zachowana naweł w przypadku całkowitego wyburzenia obiektów wchodzących w jego skład (Drukarnia Gruenavera), a z drugiej może zostać poważnie zachwiana w przypadku zachowania i konserwacji budynków historycznych (Browar Wielkopolski, rzeźnia miejska). Uzupełnianie zabudowy obiektami utrzymanymi w industrialnej stylistyce, naweł całkowicie współczesnymi w formie, sprzyja ukierunkowaniu refleksji użyt-

17 W.J. Affelt, 2014. Program..., op. cit., s. 27. 
kowników na przemysłowa historię miejsca (Fabryka Obuwia Weynerowskiego). Jednak bez dodatkowej rzetelnej informacji stylistyka ta może zostać odebrana jedynie jako modna kreacja architektoniczna, nieposiadajaca kontekstu historycznego (Rafineria Spirytusu Frankego przy ul. Podwale 2).

Stworzenie „muzeum fabryki" w jej własnych murach (Exploseum - centrum techniki wojennej DAG Fabrik Bromberg) wydaje się najkorzystniejszym wyborem dla zachowania czytelności historii miejsca i z †ego względu należałoby tak postępować w przypadku najbardziej wartościowych obiektów. Jednak warto zwrócić uwagę, że funkcja muzealna możne stawiać bardzo wysokie wymagania względem architektury, np. utrzymanie odpowiedniego mikroklimatu umożliwiającego ekspozycję zbiorów, zabezpieczenie zbiorów przed kradzieża czy odpowiednie nasłonecznienie. Dlatego też w przypadku lokalizacji muzeum w obiektach zabyłkowych należy dołożyć szczególnych starań przy dostosowaniu formy muzeum i prezentowanych zbiorów do możliwości architektury.

Niewątpliwie nawet najlepiej zachowany obiekt jeżeli nie potrafi w sposób czyłelny przekazywać swojej historii odbiorcom, nie będzie w stanie pozostawać nośnikiem zbiorowej tożsamości. A jego przemysłowa przeszłość - zamiast zostać utrwalona - będzie ulegała stopniowemu zbiorowemu zapomnieniu.

\section{LITERATURA}

[1] Affelt W.J., 2014. Program funkcjonalno-użytkowy rewitalizacji zasobu dziedzictwa techniki wobec jego wartościowości i pamięci kulturowej. [W:] Wartość funkcji w obiektach zabytkowych, red. B. Szmygin, Polski Komitet Narodowy ICOMOS, Muzeum Pałac w Wilanowie, Politechnika Lubelska, Warszawa.

[2] Affelt W.J., 2015. Technitas: konteksty dziedzictwa kulturowego techniki. Muzeum Górnictwa Węglowego w Zabrzu, Zabrze.

[3] Esman J., 2013. Rzeźnia Miejska w Bydgoszczy 1939-1945. [W:] Kronika Bydgoska, T. 34, Towarzystwo Miłośników Miasta Bydgoszczy, Bydgoszcz.

[4] Grzybowska M., Karta Ewidencyjna Zabytków Architektury i Budownictwa z roku 1995: Dom mieszkalny Gruenavera, ob. budynek główny administracji w zespole Drukarni Gruenauera, ob. Zakłady Graficzne im. KEN S. A., przechowywane w zbiorach Wojewódzkiego Urzędu Ochrony Zabyłków w Toruniu, Delegatura w Bydgoszczy.

[5] Kamosiński S., 2007. Mikroekonomiczny obraz przemysłu Polski Ludowej w latach 1950-1980 na przykładzie regionu kujawsko-pomorskiego, Wydawnictwo Poznańskie, Poznań.

[6] Kamosiński S., 2015. Przedsiębiorstwa w przebudowie. Prywatyzacja i restrukturyzacja przedsiębiorstw kujawsko-pomorskich w latach 1990-2004, Wydawnictwo Uniwersytetu Kazimierza Wielkiego, Bydgoszcz.

[7] Program opieki nad zabytkami Miasta Bydgoszczy na lata 2013-2016. [W:] Uchwała nr XLI/875/13 Rady Miasta Bydgoszczy z dnia 24 kwietnia 2013 r.

[8] Pszczółkowski M., 2010. Betonowa tajemnica. Fabryki materiałów wybuchowych DAG. Muzeum Okręgowe im. Leona Wyczółkowskiego w Bydgoszczy, Bydgoszcz.

[9] Pszczółkowski M., 2016. DAG Fabrik Bromberg. Z dziejów bydgoskiej fabryki materiałów wybuchowych 1939-1945. Muzeum Okręgowe im. Leona Wyczółkowskiego w Bydgoszczy, Bydgoszcz. 
[10] Tajchman J.J., 2014. Standardy w zakresie projektowania, realizacji i nadzorów prac konserwatorskich dotyczacych zabytków architektury i budownictwa. Narodowy Instytut Dziedzictwa, Toruń - Warszawa.

[11] Umiński J., 2009. Zakłady Graficzne. [W:] Kalendarz Bydgoski na rok 2010. Towarzystwo Miłośników Miasta Bydgoszczy, Bydgoszcz.

[12] Wracaja sklepy do Drukarni w Bydgoszczy! Będzie Nowa Drukarnia, Gazeta Pomorska, [on-line:] https://pomorska.pl/wracaja-sklepy-do-drukarni-w-bydgoszczy-bedzie-nowa-drukarnia/ar/c3-14415681 (dostęp: 19.05.2020).

\title{
CZYTELNOŚĆ HISTORII KOMPLEKSU PRZEMYSKOWEGO PO JEGO ADAPTACJI DO NOWEJ FUNKCJI. OMÓWIENIE NA KILKU BYDGOSKICH PRZYKŁADACH
}

\begin{abstract}
STRESZCZENIE. Adaptacja kompleksów poprzemysłowych do nowych funkcji użyłkowych niesie ze soba szereg specyficznych trudności. Człowiek, będqcy punktem odniesienia dla niemal wszystkich funkcji użytkowych budynków, w architekturze przemysłowej schodzi na drugi plan. Skala i organizacja obiektów fabrycznych dostosowana jest wyłącznie do wymagań maszyn i przebiegu linii produkcyjnych. Dlatego kiedy przestrzenie te trzeba adaptować do nowej funkcji użyłkowej, podstawa jest zapewnienie komfortu jego nowym użytkownikom, przy jednoczesnym zachowaniu najważniejszych wartości dziedzictwa przemysłowego.

Dziedzictwo przemysłowe - jako pełnoprawny element dziedzictwa kulturowego - stanowi element tożsamości mieszkańców. Z tego względu jego zachowanie po ustaniu funkcji produkcyjnej nie powinno podlegać dyskusjom (mowa oczywiście o wybranych kompleksach o wysokich wartościach kulturowych). Ponadto istniejące już budynki przemysłowe stanowią wartość materialna, której wtórne wykorzystanie, również ze względów ekonomicznych, wydaje się zasadne. Co więcej, w ostatnich latach pojawiła się wyraźna moda na industrialna stylistykę $w$ architekturze, która mobilizuje inwestorów do adaptowania przestrzeni poprzemysłowych. Czy jednak współczesne adaptacje obiektów poprzemysłowych potrafia przekazać użytkownikowi informacje na temat historii miejsca? Czy zachowuja najważniejsze wartości kulturowe adaptowanych zespołów? Czy moda na industrialna stylistykę w architekturze pomaga przekazywać prawdziwe informacje o dziedzictwie przemysłowym czy jedynie sprzyja scenograficznym aranżacjom?

Autorka w publikacji stara się odpowiedzieć na te pytania w oparciu o kilka przykładów adaptacji kompleksów poprzemysłowych do współczesnych funkcji użyłkowych z terenu miasta Bydgoszczy.
\end{abstract}

Słowa kluczowe: dziedzictwo przemysłowe, kompleksy poprzemysłowe, adaptacja, wartości kulturowe

\section{READABILITY OF THE HISTORY OF THE INDUSTRIAL COMPLEX AFTER ITS ADAPTATION TO THE NEW FUNCTION. DISCUSSION BASED ON SEVERAL EXAMPLES FROM BYDGOSZCZ}

SUMMARY. Adaptation of post-industrial complexes to new utility functions entails a number of specific difficulties. Man, being the reference point for almost all utility functions of buildin$\mathrm{gs}$, in industrial architecture comes to the background. The scale and organization of factory facilities is only adapted to the requirements of the machines and the course of production lines. Therefore, when these spaces need to be adapted to a new utility function, the basis is to ensure the comfort of its new users, while maintaining the most important values of industrial heritage. 
Industrial heritage, as a full-fledged element of cultural heritage, constitutes a part of the identity of residents. Therefore, its behaviour after the cessation of the production function should not be subject to discussion (of course, only selected complexes with high cultural values are being discussed). In addition, existing industrial buildings are a material value, the re-use of which, also for economic reasons, appears to be justified. Moreover, in recent years there has been a clear fashion for industrial style in architecture that mobilizes investors to adapt post-industrial spaces. However, are contemporary adaptations of post-industrial facilities able to provide the user with information about the history of the place? Do they retain the most important cultural values of the adapted complexes? Does the fashion for industrial style in architecture help to convey actual information about industrial heritage, or is it only conducive to scenographic arrangements?

As a part of the article, the author tries to answer these questions, based on several examples of adaptation of post-industrial complexes to contemporary utility functions from the city of Bydgoszcz.

Key words: industrial heritage, post-industrial complex, adaptation, cultural values 